\title{
Effect of topical aloe vera on the process of healing of full-thickness skin burn: a histological and immunohistochemical study
}

\author{
Ahmed A.M. Abdel Hamid* and Mona FM Soliman \\ *Correspondence: drahmadabdelhamid@gmail.com

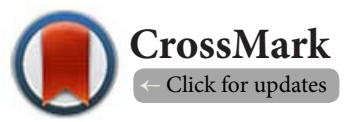

Department of Histology and Cell Biology, Faculty of Medicine, Mansoura University, Egypt.

\begin{abstract}
Background: Skin burn is common universal problem that may lead to ugly scarring, serious handicapping. Availability of natural biological treatment to improve its outcome becomes concern of many researchers.

Aim of study: To explore the effect of aloe vera on the angiogenesis process during healing of a fullthickness experimental skin burn.

Materials and methods: Seventy rats were divided into three groups; control group (A), group B and group C. Group B was exposed to full-thickness (FT) skin burn. Group C was exposed to FT skin burn with application of local aloe vera (AV) gel. Each of group B and C was divided into 3 subgroups from which skin specimens were taken at 4,8,12 days. Skin specimenswere prepared for histological and immunohistochemical study by hematoxlyin and eosin (H\&E), Masson`s trichrome (MT) and alpha smooth muscle actin ( $\alpha-S M A)$. All data were measured morphometrically and statistically analyzed.

Results: After 4 days from inducing FT burn, the initial necrosis and inflammation gradually replaced by increased granulation tissue (GT) on $8^{\text {th }}$ and $12^{\text {th }}$ day skin specimens. The collagen deposition of GT increased progressively to make a coarse dense bundles, meanwhile the newly formed capillaries (NFC) of GT were surrounded by pericytes that showed extensive expression of $\alpha$-SMA early on $4^{\text {th }}$ and till $8^{\text {th }}$ day specimens and decreased on $12^{\text {th }}$ day specimens. AV-treated groups showed relative decrease of a-SMA detection especially in $8^{\text {th }}$ and $12^{\text {th }}$ day specimens together with a significant decrease in the inflammatory infiltrate in all phases as well as deposition of more mature and finer collagen fibers compared with burn per se specimens.

Conclusion: In full-thickness skin burn, aloe vera shows a beneficial effect by reducing the inflammation significantly and providing a more mature granulation tissue which could accelerate healing and might produce a sound well-remodeled scar.
\end{abstract}

Keywords: Full-thickness skin burn, aloe vera, pericytes, inflammation, healing

\section{Introduction}

Skin burn wound injury is ranked fourth in all injuries [1]. It can severely affect not only the skin but the whole body according to their depth and extension [2]. Although there are advances in its treatment the incidence of scarring remains high [3] and the deaths are over 300,000 each year throughout the world [1].

Healing of burn wound is essentially dependent on the angiogenesis which is the mainstay in the granulation tissue formation [4]. Apart from that they are considered as progenitor/stem cells, pericytes are bone marrow-derived cells (BMDC) embedded within the basement membrane of capillaries [5,6]. During the process of angiogenesis, there is a very intimate interaction between endothelial cells and pericytes $[7,8]$. Furthermore, pericytes play a key role not only in the proliferation and migration of the endothelium and but also in their stabilization [5]. In addition, the transmigrated inflammatory cells interact with the endothelial basement membrane to enter the site of injury [4].

Several natural substances had been tried to improve burn healing; honey is claimed to delay healing in both partial-and full-thickness burns [9]. On the other hand, topical application of curcumin showed beneficial effects in the acceleration of partial-thickness burns healing [10]. 
Aloe vera (AV) is a cactus-like perennial succulent that belongs to the Liliaceae Family that is usually cultivated in tropical areas [11]. It is the one of oldest medicinal substances that was used in wound healing [12]. AV has a potentially significant anti-inflammatory effect, therefore it could be used in treating: gingivitis [12-14], skin wound [15-17] and first to second degree burns $[18,19]$. Topical application of AV has been demonstrated to have a promising effect on the wound healing process [15]. It might have greater efficacy over silver sulfadiazine cream for treating second-degree burns [18]. However, other study claimed that AV did not increase burn healing [11] or even delayed the healing process of the burn compared with silver sulfadiazine cream [20]. In addition, it might increase production of human fibroblasts 6-8 folds faster than conventional, improve their structure and accelerate their collagen production [21].

The aim of this study was to explore the effect of $A V$ on the process of healing specially angiogenesis in full thickness (FT) skin burn and to find out whether it improves this healing or not and the mechanism by which it acts.

\section{Material and methods Animals}

In the current study, 70 adult male albino rats weighing $180-$ $200 \mathrm{gm}$ were provided by Animal Housing of the Mansoura Faculty of Pharmacy. The animals were placed in standard plastic cages ( 2 animals per cage) for 12 days under $12 / 12$ hours light/dark cycle with $23-25^{\circ} \mathrm{C}$ room temperature. All animals were received standard laboratory animal's chow and water ad labitum during the whole period of experiment. The experiment was performed according to the guide for the care and use of laboratory animals (Institute for Laboratory Animal Research, National Research Council, Washington, DC: National Academy Press, no. 85-23, revised 1996).

\section{Experimental procedure}

For the experiment, animals received general anesthesia by intramuscular injection of Ketamine hydrochloride (Ketalar ${ }^{\circledR}$, Parke-Davis), $85 \mathrm{mg} / \mathrm{kg}$ of body weight, and Xylazine hydrochloride (Rompun ${ }^{\circledR}$, Bayer), $6 \mathrm{mg} / \mathrm{kg}$ of body weight each. Then the hair on the back of the dorsal region was removed. FT skin burns were produced to each animal by using a cone-shaped, stainless steel specially-made metal instrument (purchased from Hisham Medical Company, Mansoura, Egypt) equipped with a control thermometer and heated to $100^{\circ} \mathrm{C}$ in a pot of boiling water for 5 seconds. Then this instrument was applied on the upper back of the rat to produce a FT burn of an area of about $2-3 \mathrm{~cm}^{2}$. A dry dressing was applied to the wound of each, after inducing the burn, Daily monitoring of the animals and the burned wound were done.

\section{Aloe vera gel preparation}

Plant leaves of AV were obtained from and processed in the Department of Pharmacognosy and Medicinal Plants, Mansoura
Faulty of Pharmacy. After cleaning and disinfection, the gel was extracted by an incision in the plant leaves, which then was exposed to heat at $50^{\circ} \mathrm{C}$ and filtered. Glycerin and triethanolamine were added to achieve purity of AV gel of $95 \%$ which was administrated at a concentration of $200 \mathrm{mg} /$ $\mathrm{kg}[22,23]$.

\section{Experimental design}

Group A: control group contained 10 animals.

Group B: 30 animals were left to spontaneous healing. The animals were randomly divided into three subgroups of 10 animals each. Under general anesthesia, from each subgroup the burnt skin area was collected, at 4,8,12 days postburn. Group C: 30 animals had topical AV gel application once daily at a concentration of $200 \mathrm{mg} / \mathrm{kg}$ on the burnt skin. Then animals were randomly divided into three subgroups of ten animals each. Under general anesthesia, from each subgroup the burnt skin area was collected at $4,8,12$ days postburn.

\section{Histological study}

Specimens were taken from the burnt skin of spontaneouslyhealed animals as well as from AV treated ones. Specimens were processed for light microscopic examination and fixed in $10 \%$ neutral-buffered formalin. They were then processed for preparation of serial paraffin sections ( $5 \mu \mathrm{m}$ thick). Then, these sections were stained with H\&E and MT stains [24].

\section{Immunohistochemical study}

Sections of $3 \mu \mathrm{m}$-thick were cut and collected on poly-L-lysine coated slides for the immunohistochemical study. Then the slides were left for 24 hours to dry at $37^{\circ} \mathrm{C}$ for ideal adhesion of the specimens to the surface of the slide. Following deparaffinization, hydration and antigen retrieval, sections were cooled down to room temperature. Next, they were incubated for 30 minutes in $1 \% \mathrm{H}_{2} \mathrm{O}_{2}$ solution and washed in PBS, then followed by blocking in $2 \%$ skim milk for 30 minutes. The slides were incubated with the primary antibodies at $40^{\circ} \mathrm{C}$ for a night, and the next day, a peroxidase polymer-based secondary detection system (Dako, Heliopolis, Cairo, Egypt) was used for 30 minutes for signal amplification. 3, 3'-diaminobenzidine (DAB) (Dako, Egypt) was used for signal detection and the slides were counterstained by Hematoxylin then coverslipped. The mouse anti-a-SMA primary antibodies (Dako, Egypt) were used at dilution 1:100 for the immunohistochemical study according to the standard guidelines. They stain pericytes of blood capillaries, meanwhile

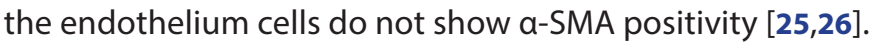

\section{Morphometric study}

The sections were imaged with a microscope (Olympus, Japan) equipped with a digital camera connected to a computer and were randomly evaluated by two 8-year experience histologists under blindfold conditions.

Qualitative assessment of the phases of healing was done 
by employing a scoring system (0-3) for each section in various groups. This system is basically dependent on specific selected parameters which are: the inflammatory cells, the collagen deposition, the angiogenesis and the granulation tissue (Table 1) $[10,27,28]$. The extent of collagen deposition was qualitatively evaluated by MT stain, while the other parameters were qualitatively assessed using H\&E stained sections.

Table 1. Histological scoring system for skin burn healing evaluation according to the listed specific parameters.

\begin{tabular}{lllll}
\hline & $\mathbf{0}$ & $\mathbf{1}$ & $\mathbf{2}$ & $\mathbf{3}$ \\
\hline Inflammatory cells & None & Minimal & Mild & Evident \\
Collagen deposition & None & Minimal & Mild & Evident \\
Angiogenesis & None & Minimal & Mild & Evident \\
Granulation tissue & None & Minimal & Mild & Evident \\
\hline
\end{tabular}

Quantitative assessment of the neovascularization during the healing process in the GT was carried out. Four images from areas of maximum density of vessels(NFC) were captured in each specimen that stained by anti-a-SMA (with an $\times 20$ objective) in each group. Then, they were digitally imported to a professional image analyzer software (Image Pro Plus 6.0, Media Cybernetics, Bethesda, MD). Both the areas and numbers (densities) of the neovascularization in the GT in the specimens of each group were assessed.

The average of all values measured from images of the same slide was used, and the results were expressed as average vascular areas $/ 1000 \mu \mathrm{m}^{2}$, and average vessel numbers $/ 1 \mathrm{~mm}^{2}$ respectively [7].

\section{Statistical analysis}

All statistical data analysis and graphs were carried out using SPSS 16.0 (SPSS, Chicago, IL, USA) and Microsoft Excel 13. Data were presented in mean \pm standard deviations (SD) by using ANOVA test for dual comparisons between groups, except the scoring system of healing which was evaluated by Mann-Whitney $U$ test. The differences were considered significant when probability $(\mathrm{P})$ was less than 0.05 .

\section{Results}

By H\&E stain in the control group, the skin was formed of dermis and epidermis. The dermis was divided into papillary layer and reticular layer. The papillary layer contained dermal papillae, blood vessels and loose connective tissue (CT) with fine collagen fibers, while the reticular layer contained dense $C T$ with coarse collagen fibers which stained blue by MT (Figures 1A-1C). Minimal a-SMA expression could be detected in the capillaries of the papillary layer of the dermis (Figure 1D).

After 4 days from inducing FT burn, sections in the skin stained by H\&E stain showed coagulative necrosis involving the whole thickness of the skin with tissue loss of the
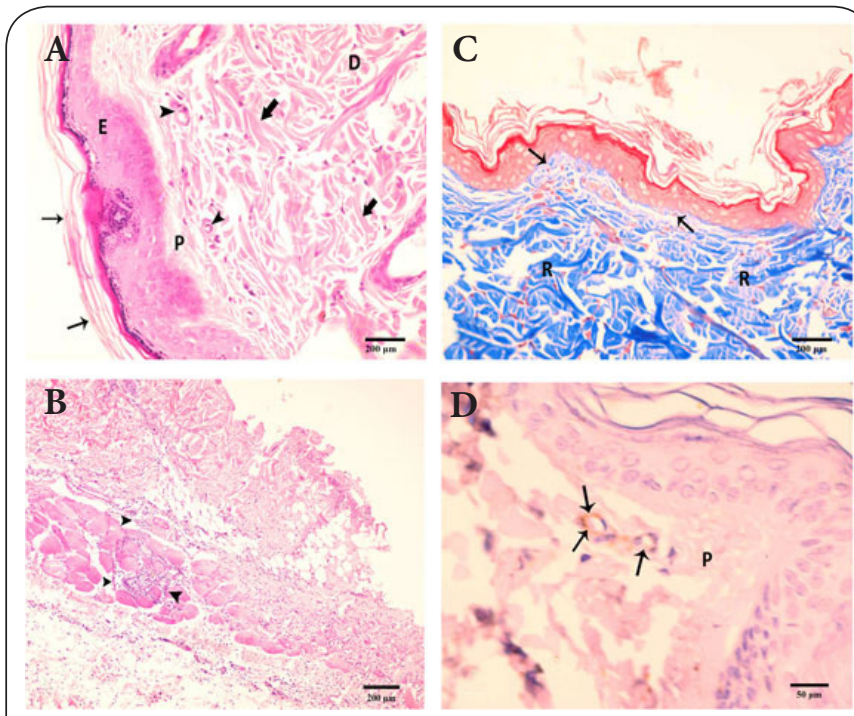

Figure 1. Photomicrographs of thin skin sections.

(A) A section in thin skin of control group showing the two layers of the skin; epidermis (E) and dermis (D). The epidermis is formed of stratified squamous keratinized epithelium (arrows) covered by a thin layer of keratin. The dermis is formed of papillary layer containing abundant blood vessels (arrowheads) surrounded fine collagen while the reticular layer is formed mainly of coarse collagen (thick arrows). (H\&E, x200, Scale bar $=200 \mu \mathrm{m}$ ). (B) A section in thin skin 4 days post burn involving the whole layers of the skin in the form of tissue loss of the epidermis and coagulation necrosis of the dermis with infiltration of the deep dermis with mononuclear cell infriltrate (arrowheads) extending to the muscle layer. (H\&E, x200, Scale bar $=200 \mu \mathrm{m})$. (C) A section in thin skin of control group showing fine collagen fibers in the papillary layer stained light blue (arrows) while the reticular layer $(\mathrm{R})$ contains more dense collagen bundles stained deep blue. (MT, x200, Scale bar $=200 \mu \mathrm{m}$ ). (D) A section in thin skin of control group showing negative to weak positive $\alpha$-SMA expression (arrows) in the blood capillaries in the papillary layer $(P)$ of the dermis. ( $\alpha$-SMA immunostaining, x1000, Scale bar $=50 \mu \mathrm{m})$.

epidermis and superficial layer of dermis fibers (Figure 1B). By higher magnification, there were severely congested blood vessels and marked infiltration of the dermis by significant mononuclear inflammatory cells in the GT appeared at base of the burnt area. This GT was formed of collagen fibers and NFC. Fibroblasts were the predominant cells between the collagen fibers (Figure 2A). On the other hand, in sections of 4 days skin burn treated with $A V$, there were less inflammatory cells infiltrate in the GT deposited at the base of the burnt area (Figure 2B).

After 8 and 12 days from inducing FT burn, in sections of the skin stained by H\&E stain, the GT showed porgessive significant increase in the vascularity by appearance of more NFC toghther with deposition of significantly more collagen rather than inflammatory cells (Figures $\mathbf{2 C}$ and $2 \mathrm{E}$ ) (Histograms $\mathbf{2}$ and $\mathbf{3}$ ). On the other hand, in skin sections of 8,12 days skin burn treated with AV, the inflammatory cells infiltrate were decreased 

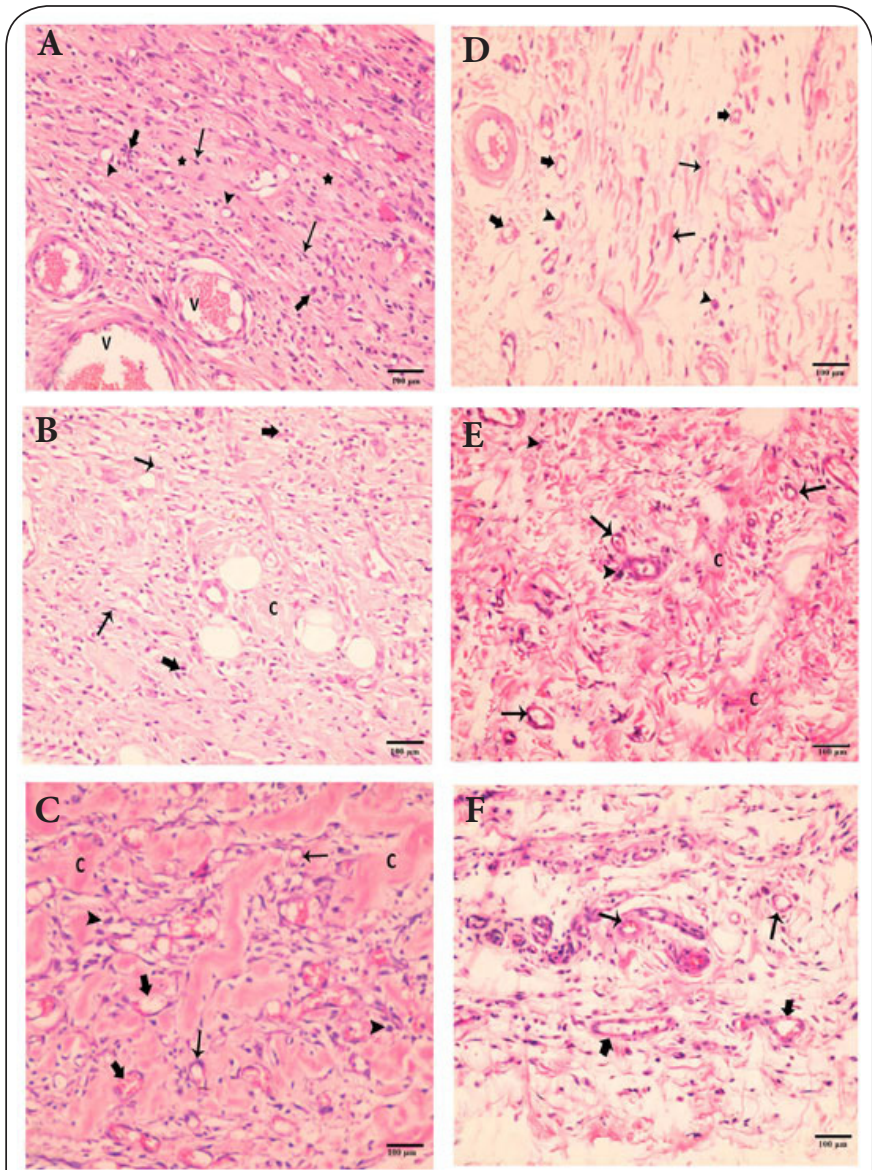

Figure 2. Photomicrographs of a H\&E (x400) sections.

(A) A section in thin skin 4 days post burn showing inflitration of the deep dermis with GT contining both collagen fibres $\left(^{*}\right)$ and NFC (arrowheads). Larger sized blood vessels (V) appear congested and surrounded by mononuclear inflammatory cells (thick arrows) together with other CT cells mainly fibroblasts (arrows). (H\&E, $x 400$, Scale bar $=100 \mu \mathrm{m}$ ). (B) A section in thin skin 4 days post burn treated with AV showing GT containing abundant less coarse collagen bundles (C) with abundant CT cells specially fibroblasts (arrows) in between. Fewer inflammatory cells (thick arrows) are seen compared with 4-d skin burn per se group. (H\&E, x400, Scale bar $=100 \mu \mathrm{m}) .(\mathrm{C})$ : A section in thin skin 8 days post burn showing increased number of immature NFC (arrows) which have sometimes incomplete wall (thick arrows) with a relatively decreased number of inflammatory cells (arrowheads) lying between the coarse collagen bundles (C). (H\&E, $\mathrm{x} 400$, Scale bar $=100 \mu \mathrm{m})$. (D) A section in thin skin 8 days post burn treated with AV showing increased number of NFC (thick arrows) and marked decrease in the inflammatory cells (arrowheads) lying in fine collagen fibers (arrows). (H\&E, $\mathrm{x} 400$, Scale bar $=100 \mu \mathrm{m}$ ). (E) A section in thin skin 12 days post burn showing increased GT formation in the form of increased density of the numerous NFC (arrows) lying in the abundant irregular collagen fibers $(\mathbf{C})$ which enclose less mononuclear inflammatory cells (arrowheads). (H\&E, $\mathrm{x} 400$, Scale bar $=100 \mu \mathrm{m}$ ). (F) A section in thin skin 12 days post burn treated with AV showing increase of the NFC (arrows) with appearance of larger-sized blood vessels (thick arrows) in the GT. (H\&E, x400, Scale bar $=100 \mu \mathrm{m})$.

significantly in the deposited GT compared with burn per se group (Figures 2D and 2F); (Histogram 1).

By MT stain, after 4 days of the burn, skin sections showed collagen deposition which appeared blue in color which

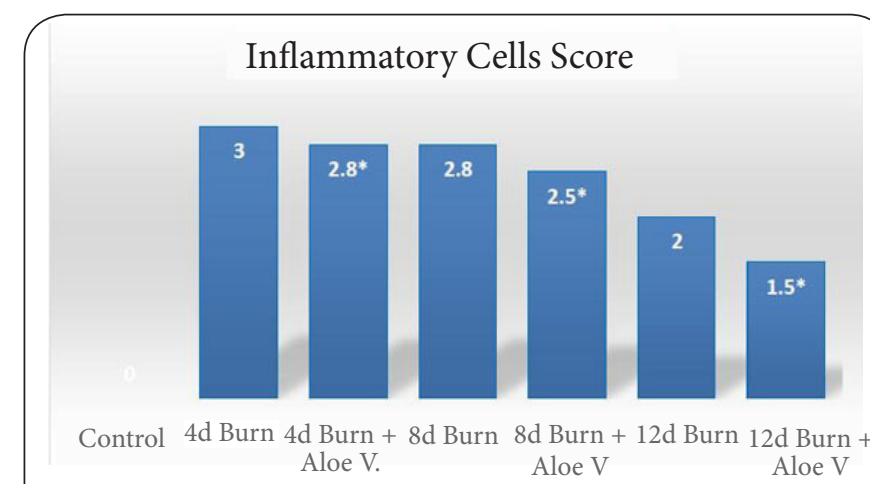

Histogram 1. Inflammatory cells score. It shows qualitative assessment of healing taking the inflammatory cells as one parameter of this assessment. ${ }^{*}$ Significant difference between the means of all the groups $(\mathrm{p}<0.05)$.
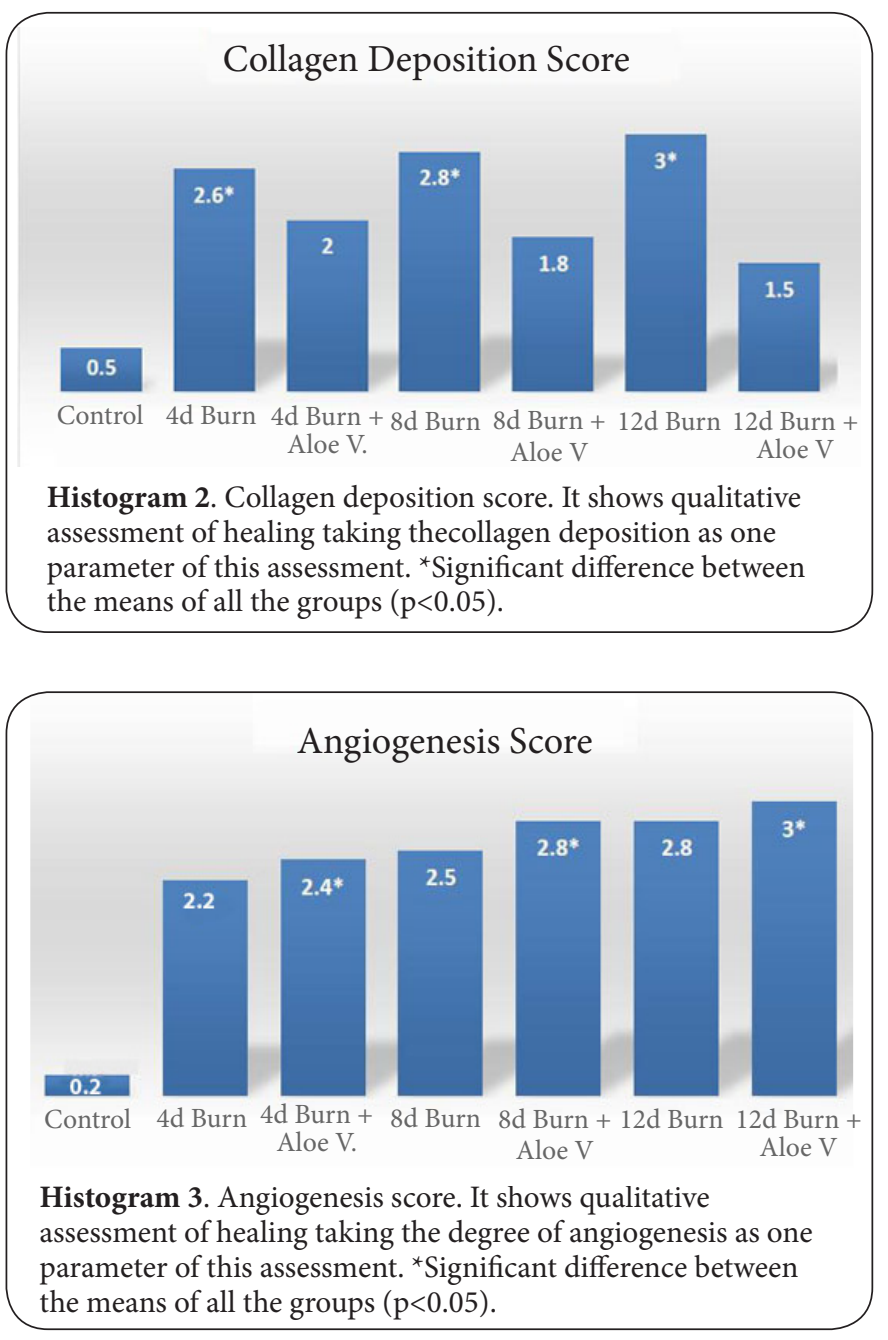
progressively increased on $8^{\text {th }}$ and $12^{\text {th }}$ day sections (Figures $3 \mathrm{~A}$, $3 \mathrm{C}$ and $3 \mathrm{E}$ ). On the other hand, in the groups treated with AV after 4,8 and 12 days of the burn, skin sections showed much fine, less dense and more well-remodeled bluish collagen fibers compared with burn per se groups (Figures 3B, 3D and 3F); (Histograms 2 and 4).

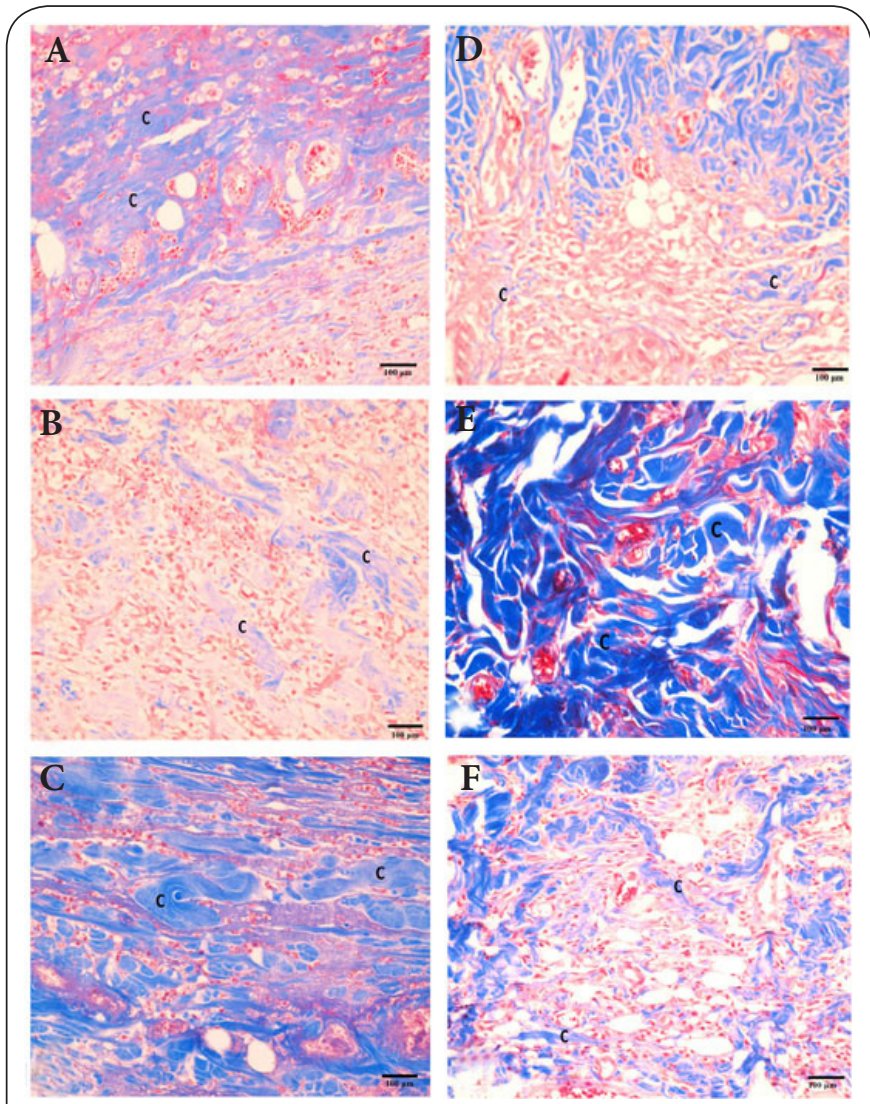

Figure 3. Photomicrographs of MT (x400) sections.

(A) A section in thin skin 4 days post burn showing coarse thick bundles of collagen (C) stained blue. (MT, x400, Scale bar $=100 \mu \mathrm{m}$ ). (B) A section in thin skin 4 days post burn treated with AV showing much more fine collagen bundles $(\mathbf{C})$ compared with A. (MT, x400, Scale bar $=100 \mu \mathrm{m}$ ). (C) A section in thin skin 8 days post burn showing excessive irregular dense collagen deposition (C). (MT, x400, Scale bar=100 $\mu \mathrm{m}$ ). (D) A section in thin skin 8 days post burn treated with AV showing finer and more regular collagen fibers $(\mathbf{C})$ in the GT compared with C. (MT, x400, Scale bar $=100 \mu \mathrm{m})$. (E) A section in thin skin 12 days post burn showing increased the deposition of coarse collagen fibers (C) in the GT of the dermis. (MT, x400, Scale bar $=100 \mu \mathrm{m}$ ). (F) A section in thin skin 12 days post burn treated with AV showing well-formed collagen deposition (c) in the dermis. (MT, $x 400$, Scale bar $=100 \mu \mathrm{m}$ ).

By a-SMA immunostain, in the 4 and 8 days burn per se group, skin sections showed progressive increase in the a-SMA expression in the pericytes surrounding the immature variable size NFC in the GT. This expression become less detected on $12^{\text {th }}$ day sections postburn per se. The immaturity of NFC

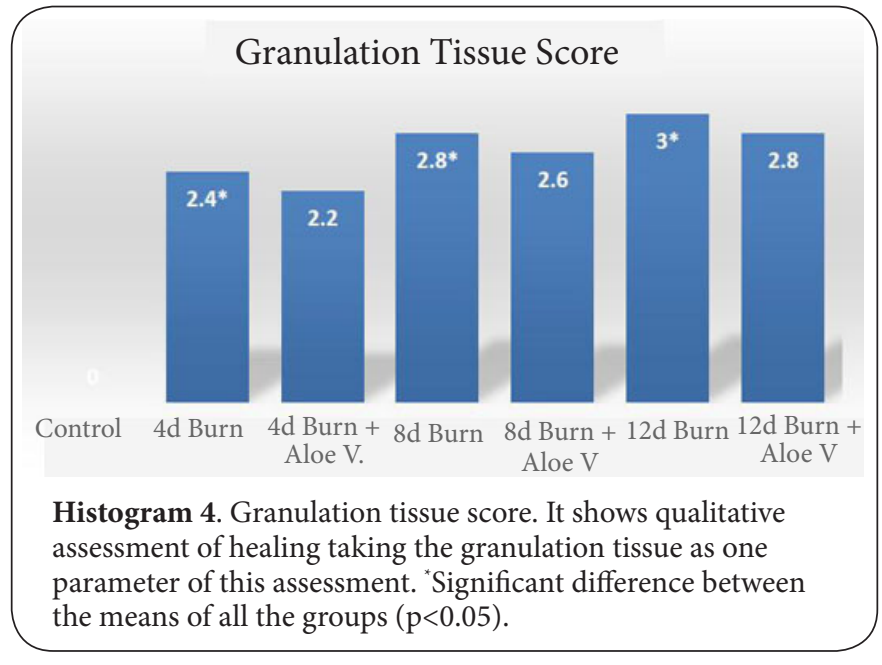

appeared both in their size and shape; some of these NFC were small in size while the other are larger. Many of the NFC were multilayered and their lumen sometimes ranged from obliterated to partially- to fully-lumenized NFC. This NFC immaturity appeared on $4^{\text {th }}$ and reached maximum on $8^{\text {th }}$ day postburn per se then they become more mature in both size and shape on the $12^{\text {th }}$ day sections as most these NFC were luminized with disappearance of the multilayered wall. In addition, the endothelium lining of these NFC showed always negative $a-S M A$ expression in all sections(Figures $4 A$, 4C and 4D).

In sections of 4,8 and 12 days skin burn treated with $A V$, the a-SMA expression was less detected and moderate in intensity compared with burn per se groups, then this expression decreased progressively on the $8^{\text {th }}$ day till it became minimally detected in most of the pericytes on the $12^{\text {th }}$ day postburn (Figure 4B). Moreover, in sections of 8 and 12 days skin burn treated with AV, NFC size as well as lumen was relatively more uniform, reflecting more mature NFC compared with burn per se groups (Figures 4B, 4E and 4F). In addition, there was a significant increase in vascular numbers (densities) as well as areas on $4^{\text {th }}, 8^{\text {th }}$ and $12^{\text {th }}$ day postburn groups treated with AV compared with non treated groups (Tables $\mathbf{2}$ and $\mathbf{3}$ ).

\section{Discussion}

After 4 days from inducing FT skin burn, there was coagulative necrosis which is healed by GT appeared at base of the burnt area. On $8^{\text {th }}$ and until $12^{\text {th }}$ day from inducing the FT skin burn, the vascularity of the GT is increased by appearance of more NFC together with deposition of more collagen rather that inflammatory cells. These results were in agreement with previous studies $[\mathbf{7 , 2 9 ]}$. Fibroblasts were always the predominant $\mathrm{CT}$ cells in the GT regardless the stage of healing. The core function of fibroblasts is the formation of collagen, which is a supportive protein that responsible for the skin to be firm [21]. Therefore, these non-inflammatory BMDCs are essential for homeostasis and healing of the skin [30]. 

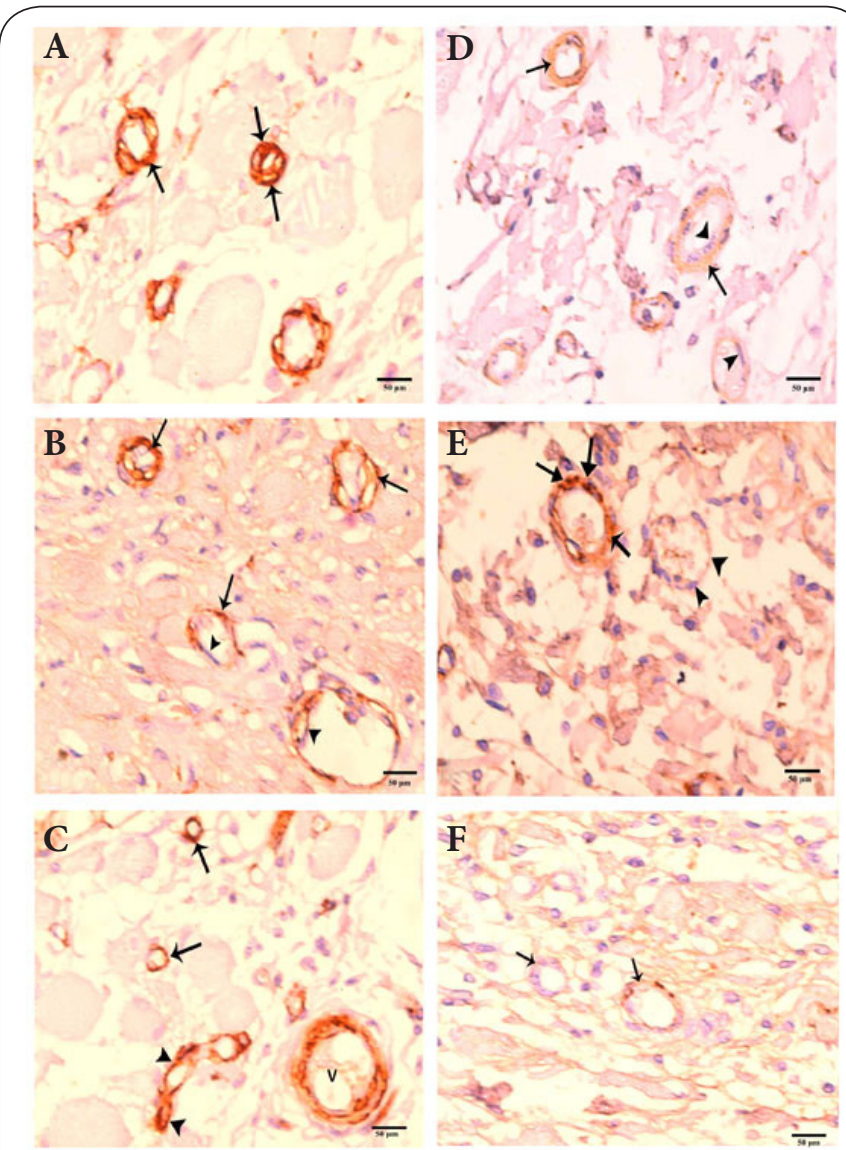

Figure 4. Photomicrographs of $\alpha$-SMA immune-stained (x1000) sections.

(A) A section in thin skin 4 days post burn showing increased number of immature multilayered NFC with strong positive a-SMA-stained pericytes (arrows). (a-SMA immunostaining, $\mathrm{x} 1000$, Scale bar $=50 \mu \mathrm{m}$ ). (B) A section in thin skin 4 days post burn treated with AV showing immature variable size NFC made up of two rows of cells: internal negative $a$-SMAstained endothelial cell (arrowheads) and external positive a-SMA-stained pericytes (arrows) surrounding the lumen which appears partially obliterated in some and fully canalized in others. ( $\alpha$-SMA immunostaining, $x 1000$, Scale bar $=50 \mu \mathrm{m}$ ). (C) A section in thin skin 8 days post burn showing increased density of the immature variable-sized NFC surrounded by positive $\alpha$-SMA-stained pericytes (arrows). Blood vessels sometimes appear as partially erupted cord (arrowheads) and occasionally acquire more layers to form a larger vessel (V). ( $\alpha$-SMA immunostaining, $x 1000$, Scale bar $=50 \mu \mathrm{m}$ ).

(D) A section in thin skin 8 days post burn treated with AV showing more mature NFC with patent lumen lined by negative $\alpha$-SMA-stained endothelium (arrowheads) surrounded by moderately positive $\alpha$-SMA-stained pericytes (arrows). ( $\alpha$-SMA immunostaining, $x 1000$, Scale bar $=50 \mu \mathrm{m}$ ). (E) A section in thin skin 12 days post burn showing two NFC; one shows a moderately positivea-SMA expression (arrows)while in the other no a-SMA expression could be detected (arrowheads). ( $\alpha$-SMA immunostaining, x1000, Scale bar $=50 \mu \mathrm{m})$. (F) A section in thin skin 12 days post burn treated with AV showing more mature NFC with negative a-SMA immunostaining in most of the pericytes (arrows). ( $a$-SMA immunostaining, $x 1000$, Scale bar $=50 \mu \mathrm{m}$ ).
Table 2. Average vascular areas in different groups. Average vascular areas/1000 $\mu^{2}$.

\begin{tabular}{lll}
\hline & FT Burn per se & FT Burn+AV \\
\hline $4 \mathrm{~d}$ & $42 \pm 4$ & $48 \pm 3^{*}$ \\
$8 \mathrm{~d}$ & $71 \pm 5$ & $78 \pm 2^{*}$ \\
$12 \mathrm{~d}$ & $87 \pm 4$ & $96 \pm 1^{*}$ \\
\hline
\end{tabular}

*Significant difference between the means of all the groups $(\mathrm{p}<0.05)$.

Table 3. Average vascular numbers (densities) in different groups $/ \mathrm{mm}^{2}$.

\begin{tabular}{lll}
\hline & FT Burn per se & FT Burn+AV \\
\hline $4 \mathrm{~d}$ & $86 \pm 4$ & $94 \pm 2^{*}$ \\
$8 \mathrm{~d}$ & $154 \pm 6$ & $168 \pm 3^{*}$ \\
$12 \mathrm{~d}$ & $189 \pm 6$ & $197 \pm 5^{*}$ \\
\hline
\end{tabular}

*Significant difference between the means of all the groups $(\mathrm{p}<0.05)$.

Moreover, fibroblasts crosstalk with monocytes/macrophages that infiltrate the site of injury and orchestrate the healing process and tissue repair. Monocytes dynamically react with selected extracellular matrix (ECM) components secreted by the fibroblasts. In addition, monocytes decreased fibroblast interleukin (IL)-1 $a$ and transforming growth factor-alpha (TGF)-a, however they highly increased fibroblast matrix metalloproteinase (MMP)-2 and granulocyte-macrophage colony-stimulating factor (GM-CSF) [31].

In this study, there was heavy infiltration mononuclear inflammatory cells especially initially after 4 days of inducing the burn which became milder later, when the GT acquired collagen rather than inflammatory cells. This was in agreement with other researchers [2], who claimed that macrophages initially increased by about 3 folds, then decreased gradually with maturation of the GT. Monocytes/macrophages are crucial regulatory inflammatory cells as well as the immediate arm of the innate immunity [32-34], therefore their influx into the tissue plays a critical role in the healing process. In addition, it was demonstrated that depletion of macrophages in early inflammatory phase of the healing, significantly reduced GT formation [35].

In the present study, there was significant progressive increase in the number as well as area of NFC. Macrophages, which are also BMDC, secrete proangiogenic cytokines, ECMremodeling proteases and provide physical support to the growing NFC $[6,36]$. Therefore, they could be responsible for the increased angiogenesis more than $10 \%$ in severe inflammatory reactions as in FT burns [2]. This may explain the significant increase in the vascularity from $4^{\text {th }}$ to $12^{\text {th }}$ in this study and its induction by the severity of the inflammation especially in the early reparatory phase of the burn healing.

In this experiment, in the 4 days burn per se group, skin sections showed a-SMA positive expression in the pericytes surrounding the immature variable size NFC in the GT. Then 
after 8 days from inducing the burn there was increase of the a-SMA expression in the pericytes. This might indicate increased immaturity of the NFC till 8 days post burn, then became less detected 12 days post burn specimens. These results were in agreement with previous studies [7] which demonstrated that during the process of angiogenesis, there was an intimate relationship between pericytes ( $\mathrm{a}-\mathrm{SMA}$ positive) and endothelial cells. These BMDCs, stimulated by PDGFR (platelet-derived growth factor receptors)- $\beta$, can promote mechanical support and signaling to maintain the NFC by direct interaction with endothelial cells [6]. Moreover, they could transdifferentiate into other mesenchymal cell types, including fibroblasts, smooth muscle cells or even osteoblasts. Furthermore, the increased expression of these a-SMA-positive investing pericytes could mediates sprouting as well as remodeling new vessels [37]. This might explain how essential the abundant expression of these a-SMA-positive progenitor cells specially early in $4^{\text {th }}$ to $8^{\text {th }}$ day post-burn rather than $12^{\text {th }}$ day post-burn as they might transdifferentiate into a rather mature clone of cells in the wall of the vessel.

In skin sections of 4, 8 and 12 days skin burn treated with $A V$ there were a significantly less inflammatory cells infiltrate in the GT compared with 4, 8 and 12 skin burn per se specimens respectively. These might be attributed to the potentially significant anti-inflammatory effect of AV [12-14]. Other researchers reported that in addition to its anti-inflammatory effect, AV acts as immunomodulator as well as scavenger of free radicals [38]. Moreover, previous studies demonstrated that $\mathrm{AV}$ inhibited the cyclooxygenase pathway and reduced prostaglandin E2 which might be attributed to an anti-inflammatory compound called C-glucosyl chromone isolated from AV $[38,39]$. In addition, recent studies suggest that a bradykinase isolated from $\mathrm{AV}$ could break down bradykinin, an inflammatory substance that induces pain and inflammation [21] and this might disclose the mechanisms by which AV acts as anti-inflammatory.

The collagen fibers in skin sections of 4,8 and 12 days skin burn treated with $A V$ there were less dense, thinner and more remodeled compared with 4, 8 and 12 skin burn per se specimens respectively. This was in agreement with previous studies, which postulated that AV induced more rapid maturation of collagen [40]. Some researchers attributed this action to glucomannan, a mannose-rich polysaccharide $[41,42]$. On the other hand, other researchers claimed that gibberellin, a growth hormone, interacts with receptor on the fibroblasts, thereby stimulating its activity and proliferation, which in turn accelerated collagen synthesis after topical or oral application of AV [43]. Other studies suggest that AV is an inhibitor of collagenase which might be responsible for the better remodeled collagen in the AV-treated groups [38].

In the present study, in skin sections of 4,8 and 12 days treated with AV there were gradual decrease in a-SMA expression together with gradual significant increase in density and area as well as the maturity of NFC compared with specimens of 4,8 and $12 \mathrm{~d}$ skin burn without AV resp-ectively. This was in concurrence with other researchers who postulated that $\mathrm{AV}$ improved healing by increasing angiogenesis and thereby oxygenation $[\mathbf{4 4 , 4 5}]$. This could be attributed to acemannan, a polysaccharide in $\mathrm{AV}$, which was shown to activate macrophages, an effect that improved healing in a rat model $[46,47]$. In addition, it was reported that AV stimulated blood vessel formation in the vascular chorioallantoic membrane in chicken by a glycoprotein which could promote the stimulation of endothelial cells proliferation in vitro and induced them to interact with collagen [48]. However, other studies postulated that $\mathrm{AV}$ reduced both the vascularity and mast cells number of inflamed synovial membrane to about the half [49].

Therefore, the neovascularization effect of AV might be multifactorial from tissue to other, affected not only by the hypoxia but also by the cellular interactions and molecular alterations promoted by the injury.

\section{Conclusion}

In full-thickness skin burn, aloe vera shows a beneficial effect by reducing the inflammation significantly and providing a more mature granulation tissue which could accelerate healing and might produce a sound well-remodeled scar. Based on the significantly positive results of this study, it is recommended to carry out further experimental research as well as clinical trials to standardize aloe vera as a biological treatment in skin burn.

\section{Competing interests}

The authors declare that they have no competing interests.

Authors' contributions

\begin{tabular}{|l|c|c|}
\hline Authors' contributions & AAMAH & MFMS \\
\hline Research concept and design & $\checkmark$ & -- \\
\hline Collection and/or assembly of data & $\checkmark$ & -- \\
\hline Data analysis and interpretation & $\checkmark$ & -- \\
\hline Writing the article & $\checkmark$ & $\checkmark$ \\
\hline Critical revision of the article & $\checkmark$ & $\checkmark$ \\
\hline Final approval of article & $\checkmark$ & $\checkmark$ \\
\hline Statistical analysis & $\checkmark$ & -- \\
\hline
\end{tabular}

Publication history

Editors: Karin Pichler, Medical University of Innsbruck, Austria. Lingyan Wang, Oregon Health \& Science University, Portland. EIC: Giuseppe Musumeci, University of Catania, Italy. Received: 15-Dec-2014 Final Revised: 24-Jan-2015 Accepted: 28-Jan-2015 Published: 14-Feb-2015

\section{References}

1. Peck MD. Epidemiology of burns throughout the world. Part I: Distribution and risk factors. Burns. 2011; 37:1087-100. | Article | PubMed

2. Busuioc CJ, Popescu FC, Mogosanu GD, Parvanescu H, Streba L and Mogoanta L. Histological and immunohistochemical study of cutaneous angiogenesis process in experimental third-degree skin burns treated with allograft. Rom J Morphol Embryol. 2012; 53:1061-7. | Pdf I PubMed 
3. Penn JW, Grobbelaar AO and Rolfe KJ. The role of the TGF-beta family in wound healing, burns and scarring: a review. Int J Burns Trauma. 2012; 2:18-28. | PubMed Abstract | PubMed Full Text

4. Li J, Zhang YP and Kirsner RS. Angiogenesis in wound repair: angiogenic growth factors and the extracellular matrix. Microsc Res Tech. 2003; 60:107-14. | Article | PubMed

5. Ribatti $D$, Nico $B$ and Crivellato $E$. The role of pericytes in angiogenesis. Int J Dev Biol. 2011; 55:261-8. | Article I PubMed

6. Ding $\mathrm{Y}$, Song $\mathrm{N}$ and Luo $\mathrm{Y}$. Role of bone marrow-derived cells in angiogenesis: focus on macrophages and pericytes. Cancer Microenviron. 2012; 5:225-36. | Article | PubMed Abstract | PubMed Full $\underline{\text { Text }}$

7. Busuioc CJ, Popescu FC, Mogosanu GD, Lascar I, Pirici I, Pop OT and Mogoanta L. Angiogenesis assessment in experimental third degree skin burns: a histological and immunohistochemical study. Rom J Morphol Embryol. 2011; 52:887-95. | Pdf | PubMed

8. Siemerink MJ, Klaassen I, Vogels IM, Griffioen AW, Van Noorden CJ and Schlingemann RO. CD34 marks angiogenic tip cells in human vascular endothelial cell cultures. Angiogenesis. 2012; 15:151-63. | Article | PubMed Abstract | PubMed Full Text

9. Jull $A B$, Rodgers $A$ and Walker N. Honey as a topical treatment for wounds. Cochrane Database Syst Rev. 2008; CD005083. | Article | PubMed

10. Kulac M, Aktas C, Tulubas F, Uygur R, Kanter M, Erboga M, Ceber M, Topcu $B$ and Ozen OA. The effects of topical treatment with curcumin on burn wound healing in rats. J Mol Histol. 2013; 44:83-90. | Article | PubMed

11. Dat $A D$, Poon F, Pham KB and Doust J. Aloe vera for treating acute and chronic wounds. Cochrane Database Syst Rev. 2012; 2:CD008762. | Article | PubMed

12. Ajmera N, Chatterjee A and Goyal V. Aloe vera: It's effect on gingivitis. J Indian Soc Periodontol. 2013; 17:435-8. | Article | PubMed Abstract | PubMed Full Text

13. Karim B, Bhaskar DJ, Agali C, Gupta D, Gupta RK, Jain A and Kanwar A. Effect of Aloe vera mouthwash on periodontal health: triple blind randomized control trial. Oral Health Dent Manag. 2014; 13:14-9. I PubMed

14. Gupta RK, Gupta D, Bhaskar DJ, Yadav A, Obaid K and Mishra S. Preliminary antiplaque efficacy of aloe vera mouthwash on 4 day plaque re-growth model: randomized control trial. Ethiop J Health Sci. 2014; 24:139-44. | PubMed Abstract | PubMed Full Text

15. Khan AW, Kotta S, Ansari SH, Sharma RK, Kumar A and Ali J. Formulation development, optimization and evaluation of aloe vera gel for wound healing. Pharmacogn Mag. 2013; 9:S6-S10. | Article | PubMed Abstract | PubMed Full Text

16. Feily $A$ and Namazi MR. Aloe vera in dermatology: a brief review. G Ital Dermatol Venereol. 2009; 144:85-91. | Article | PubMed

17. Mendonca FA, Passarini Junior JR, Esquisatto MA, Mendonca JS, Franchini CC and Santos GM. Effects of the application of Aloe vera (L.) and microcurrent on the healing of wounds surgically induced in Wistar rats. Acta Cir Bras. 2009; 24:150-5. I Article I PubMed

18. Khorasani G, Hosseinimehr SJ, Azadbakht M, Zamani A and Mahdavi MR. Aloe versus silver sulfadiazine creams for second-degree burns: a randomized controlled study. Surg Today. 2009; 39:587-91. | Article | PubMed

19. Maenthaisong R, Chaiyakunapruk N, Niruntraporn S and Kongkaew C. The efficacy of aloe vera used for burn wound healing: a systematic review. Burns. 2007; 33:713-8. | Article | PubMed Abstract | PubMed Full Text

20. Kaufman T, Kalderon N, Ullmann $Y$ and Berger J. Aloe vera gel hindered wound healing of experimental second-degree burns: a quantitative controlled study. J Burn Care Rehabil. 1988; 9:156-9. | Article | PubMed

21. Ahmadi A. Potential prevention: Aloe vera mouthwash may reduce radiation-induced oral mucositis in head and neck cancer patients. Chin J Integr Med. 2012; 18:635-40. | Article | PubMed

22. Rajasekaran S, Sivagnanam K, Ravi K and Subramanian S. Hypoglycemic effect of Aloe vera gel on streptozotocin-induced diabetes in experimental rats. J Med Food. 2004; 7:61-6. I Article I PubMed

23. Daburkar M, Lohar V, Rathore AS, Bhutada P and Tangadpaliwar S. An in vivo and in vitro investigation of the effect of Aloe vera gel ethanolic extract using animal model with diabetic foot ulcer. J Pharm Bioallied Sci. 2014; 6:205-12. | Article | PubMed Abstract | PubMed Full Text

24. Bancroft JD and Layton C. The Hematoxylin and eosin. In: Suvarna SK, Layton C and Bancroft JD editors. Theory \& Practice of histological techniques. $7^{\text {th }}$ ed., Churchill Livingstone of El Sevier. Philadelphia. Ch.10 and 11. 2013; 173-214. I Book

25. Jackson P and Blythe D. Immunohistochemical techniques. In: Suvarna SK, Layton C and Bancroft JD editors. Theory \& Practice of histological techniques. $7^{\text {th }}$ ed., Churchill Livingstone of El Sevier. Philadelphia. Ch. 18. 2013; 381-434. | Book

26. Busuioc CJ, Mogosanu GD, Popescu FC, Lascar I, Parvanescu H and Mogoanta L. Phases of the cutaneous angiogenesis process in experimental third-degree skin burns: histological and immunohistochemical study. Rom J Morphol Embryol. 2013; 54:163-71. | Pdf | PubMed

27. Schlager A, Oehler K, Huebner KU, Schmuth M and Spoetl L. Healing of burns after treatment with 670-nanometer low-power laser light. Plast Reconstr Surg. 2000; 105:1635-9. | Article | PubMed

28. Karadag CA, Birtane M, Aygit AC, Uzunca K and Doganay L. The efficacy of linear polarized polychromatic light on burn wound healing: an experimental study on rats. J Burn Care Res. 2007; 28:291-8. | Article | PubMed

29. Nassar MA, Eldien HM, Tawab HS, Saleem TH, Omar HM, Nassar AY and Hussein MR. Time-dependent morphological and biochemical changes following cutaneous thermal burn injury and their modulation by copper nicotinate complex: an animal model. Ultrastruct Pathol. 2012; 36:343-55. | Article | PubMed

30. Wu Y, Zhao RC and Tredget EE. Concise review: bone marrow-derived stem/progenitor cells in cutaneous repair and regeneration. Stem Cells. 2010; 28:905-15. | Article | PubMed Abstract | PubMed Full Text

31. Chung AS and Kao WJ. Fibroblasts regulate monocyte response to ECMderived matrix: the effects on monocyte adhesion and the production of inflammatory, matrix remodeling, and growth factor proteins. $J$ Biomed Mater Res A. 2009; 89:841-53. | Article | PubMed Abstract | PubMed Full Text

32. Geissmann F, Manz MG, Jung S, Sieweke MH, Merad M and Ley K. Development of monocytes, macrophages, and dendritic cells. Science. 2010; 327:656-61. | Article | PubMed Abstract | PubMed Full Text

33. Popescu FC, Mogosanu GD, Busuioc CJ, Parvanescu H, Lascar I and Mogoanta L. Macrophage response in experimental third-degree skin burns treated with allograft. Histological and immunohistochemical study. Rom J Morphol Embryol. 2012; 53:1027-36 | $\underline{\text { Article | PubMed }}$

34. Mannon RB. Macrophages: contributors to allograft dysfunction, repair, or innocent bystanders? Curr Opin Organ Transplant. 2012; 17:20-5. I Article | PubMed Abstract | PubMed Full Text

35. Lucas T, Waisman A, Ranjan R, Roes J, Krieg T, Muller W, Roers A and Eming SA. Differential roles of macrophages in diverse phases of skin repair. J Immunol. 2010; 184:3964-77. | Article I PubMed

36. Nucera S, Biziato D and De Palma M. The interplay between macrophages and angiogenesis in development, tissue injury and regeneration. Int J Dev Biol. 2011; 55:495-503. | Article I PubMed

37. Gerhardt $\mathrm{H}$ and Betsholtz $\mathrm{C}$. Endothelial-pericyte interactions in angiogenesis. Cell Tissue Res. 2003; 314:15-23. | Article | PubMed

38. Hutter JA, Salman M, Stavinoha WB, Satsangi N, Williams RF, Streeper RT and Weintraub ST. Antiinflammatory C-glucosyl chromone from Aloe barbadensis. J Nat Prod. 1996; 59:541-3. | Article I PubMed

39. Yagi A, Kabash A, Mizuno K, Moustafa SM, Khalifa TI and Tsuji H. Radical scavenging glycoprotein inhibiting cyclooxygenase-2 and thromboxane A2 synthase from aloe vera gel. Planta Med. 2003; 69:269-71. | Article | PubMed

40. Reynolds T and Dweck AC. Aloe vera leaf gel: a review update. J Ethnopharmacol. 1999; 68:3-37. I Article I PubMed

41. Tai-Nin Chow J, Williamson DA, Yates KM and Goux WJ. Chemical 
Abdel Hamid et al. Journal of Histology \& Histopathology 2015, http://www.hoajonline.com/journals/pdf/2055-091X-2-3.pdf

characterization of the immunomodulating polysaccharide of Aloe vera L. Carbohydr Res. 2005; 340:1131-42. | Article | PubMed

42. Gupta VK and Malhotra S. Pharmacological attribute of Aloe vera: Revalidation through experimental and clinical studies. Ayu. 2012; 33:193-6. | Article | PubMed Abstract | PubMed Full Text

43. Heggers JP, Kucukcelebi A, Listengarten D, Stabenau J, Ko F, Broemeling LD, Robson MC and Winters WD. Beneficial effect of Aloe on wound healing in an excisional wound model. J Altern Complement Med. 1996; 2:271-7. | PubMed

44. Yagi $A$, Egusa $T$, Arase $M$, Tanabe $M$ and Tsuji $H$. Isolation and characterization of the glycoprotein fraction with a proliferationpromoting activity on human and hamster cells in vitro from Aloe vera gel. Planta Med. 1997; 63:18-21. | Article | PubMed

45. Davis RH and Maro NP. Aloe vera and gibberellin. Anti-inflammatory activity in diabetes. J Am Podiatr Med Assoc. 1989; 79:24-6. | Article | PubMed

46. Rodriguez Rodriguez E, Darias Martin J and Diaz Romero C. Aloe vera as a functional ingredient in foods. Crit Rev Food Sci Nutr. 2010; 50:305-26. | Article I PubMed

47. Jittapiromsak N, Sahawat D, Banlunara W, Sangvanich P and Thunyakitpisal P. Acemannan, an extracted product from Aloe vera, stimulates dental pulp cell proliferation, differentiation, mineralization, and dentin formation. Tissue Eng Part A. 2010; 16:1997-2006. | Article I PubMed

48. Davis RH, Donato JJ, Hartman GM and Haas RC. Anti-inflammatory and wound healing activity of a growth substance in Aloe vera. J Am Podiatr Med Assoc. 1994; 84:77-81. | Article | PubMed

49. Davis RH, Stewart GJ and Bregman PJ. Aloe vera and the inflamed synovial pouch model. J Am Podiatr Med Assoc. 1992; 82:140-8. | Article I PubMed

\section{Citation:}

Abdel Hamid AAM and Soliman MFM. Effect of topical aloe vera on the process of healing of full-thickness skin burn: a histological and immunohistochemical study. J Histol Histopathol. 2015; 2:3. http://dx.doi.org/10.7243/2055-091X-2-3 